\title{
Highlight report: caspase 8 as a therapeutic target in chronic liver disease
}

\author{
Hermann M. Bolt ${ }^{1}[$
}

Received: 8 August 2019 / Accepted: 12 August 2019 / Published online: 17 August 2019

c) Springer-Verlag GmbH Germany, part of Springer Nature 2019

Apoptosis can be induced by extrinsic death receptor-mediated pathways (Yuan 1997; Reed 2000; Chaudhary et al. 2013) where caspase 8 acts as downstream executioner of cell death (Alnemri et al. 1996; Li et al. 2010; Desbarats and Newell 2000; Yuan 1997). In the past years, mouse models with inducible and cell type-specific deletion of caspase 8 have been established to understand how caspase 8 contributes to chronic liver disease (Chaudhary et al. 2013; Liedtke et al. 2011). The ubiquitous knockout of caspase 8 led to enhanced liver injury in mouse models of cholestatic liver damage as evidenced by a strong increase in transaminases and bilirubin as well as increased fibrosis compared to wild-type controls (Chaudhary et al. 2013). This has been explained by inhibition of apoptosis in immune cells, leading to stronger infiltration of mononuclear cells into the liver tissue and to immune cell-mediated liver damage. However, a recent landmark publication demonstrated that cell type-specific deletion of caspase 8 in parenchymal cells of the liver protects against obstructive cholestasis induced by ligation of the common bile duct (Cubero et al. 2018). The knockout of caspase 8 in cholangiocytes decreased necrotic foci and ductular reaction (Cubero et al. 2018). Therefore, caspase 8 is a promising therapeutic target in obstructive cholestasis but strategies have to be identified to inhibit caspase 8 in cholangiocytes without influencing immune cells, because inhibition in immune cells may lead to immune-mediated hepatotoxicity (Cubero et al. 2018).

Currently, mechanisms of liver damage and regeneration as well as the pathophysiology of cholestasis represent a very active field of research (Rodrigues et al. 2018; Svinka et al. 2017; Leist et al. 2017; Hoehme et al. 2010; Ghallab et al. 2016). It has been shown that cholestatic liver disease

Hermann M. Bolt

bolt@ifado.de

1 IfADo-Leibniz Research Centre for Working Environment and Human Factors, TU Dortmund, Ardeystr. 67, 44139 Dortmund, Germany usually evolves over time with an ascending course of the disease process with first lesions in bile ducts, followed by damage of liver parenchyma (Jansen et al. 2017). In this situation, concentrations of bile acids in the biliary tract increase, lead to ruptures of the apical and later basolateral hepatocyte membranes and thereby cause shunting of bile acids from canaliculi into the blood (Ghallab et al. 2019). At the level of interlobular bile ducts, cholestasis leads to adaptive remodeling by cholangiocyte proliferation, branching as well as looping of ducts, also known as ductular reaction (Vartak et al. 2016). Therefore, the concept of Cubero and colleagues (2018) to reduce apoptosis specifically in cholangiocytes to delay progression of cholestatic liver disease seems to be reasonable. However, the challenge remains how the required cell type-specific inhibition of caspase 8 can be achieved in patients.

\section{Compliance with ethical standards}

Conflict of interest The author declares that he has no conflict of interest.

\section{References}

Alnemri ES, Livingston DJ, Nicholson DW, Salvesen G, Thornberry NA, Wong WW, Yuan J (1996) Human ICE/CED-3 protease nomenclature. Cell 87(2):171

Chaudhary K, Liedtke C, Wertenbruch S, Trautwein C, Streetz KL (2013) Caspase 8 differentially controls hepatocytes and nonparenchymal liver cells during chronic cholestatic liver injury in mice. J Hepatol 59(6):1292-1298. https://doi.org/10.1016/j. jhep.2013.07.026

Cubero FJ, Peng J, Liao L et al (2018) Inactivation of caspase 8 in liver parenchymal cells confers protection against murine obstructive cholestasis. J Hepatol 69(6):1326-1334. https://doi.org/10.1016/j. jhep.2018.08.015

Desbarats J, Newell MK (2000) Fas engagement accelerates liver regeneration after partial hepatectomy. Nat Med 6(8):920-923 
Ghallab A, Cellière G, Henkel SG et al (2016) Model-guided identification of a therapeutic strategy to reduce hyperammonemia in liver diseases. J Hepatol 64(4):860-871. https://doi.org/10.1016/j. jhep.2015.11.018

Ghallab A, Hofmann U, Sezgin S et al (2019) Bile microinfarcts in cholestasis are initiated by rupture of the apical hepatocyte membrane and cause shunting of bile to sinusoidal blood. Hepatology 69(2):666-683. https://doi.org/10.1002/hep.30213

Hoehme S, Brulport M, Bauer A et al (2010) Prediction and validation of cell alignment along microvessels as order principle to restore tissue architecture in liver regeneration. Proc Natl Acad Sci USA 107(23):10371-10376. https://doi.org/10.1073/pnas.0909374107

Jansen PL, Ghallab A, Vartak N, Reif R, Schaap FG, Hampe J, Hengstler JG (2017) The ascending pathophysiology of cholestatic liver disease. Hepatology 65(2):722-738. https://doi.org/10.1002/ hep.28965 (Review)

Leist M, Ghallab A, Graepel R et al (2017) Adverse outcome pathways: opportunities, limitations and open questions. Arch Toxicol 91(11):3477-3505. https://doi.org/10.1007/s00204-017-2045-3

Li F, Huang Q, Chen J, Peng Y, Roop, Bedford JS, Li CY (2010) Apoptotic cells activate the "phoenix rising" pathway to promote wound healing and tissue regeneration. Sci Signal 3(110):ra13. https://doi.org/10.1126/scisignal.2000634

Liedtke C, Bangen JM, Freimuth J et al (2011) Loss of caspase-8 protects mice against inflammation-related hepatocarcinogenesis but induces non-apoptotic liver injury. Gastroenterology 141(6):21762187. https://doi.org/10.1053/j.gastro.2011.08.037

Reed JC (2000) Mechanisms of apoptosis. Am J Pathol 157(5):1415-1430

Rodrigues RM, Kollipara L, Chaudhari U et al (2018) Omics-based responses induced by bosentan in human hepatoma HepaRG cell cultures. Arch Toxicol 92(6):1939-1952. https://doi.org/10.1007/ s00204-018-2214-z

Svinka J, Pflügler S, Mair M et al (2017) Epidermal growth factor signaling protects from cholestatic liver injury and fibrosis. J Mol Med (Berl) 95(1):109-117. https://doi.org/10.1007/s00109-016-1462-8

Vartak N, Damle-Vartak A, Richter B, Dirsch O, Dahmen U, Hammad S, Hengstler JG (2016) Cholestasis-induced adaptive remodeling of interlobular bile ducts. Hepatology 63(3):951-964. https://doi. org/10.1002/hep. 28373

Yuan J (1997) Transducing signals of life and death. Curr Opin Cell Biol 9(2):247-251

Publisher's Note Springer Nature remains neutral with regard to jurisdictional claims in published maps and institutional affiliations. 